Ruth Endacott

\title{
The continuing imperative to measure workload in ICU: impact on patient safety and staff well-being
}

Received: 2 July 2012

Accepted: 4 July 2012

Published online: 9 August 2012

(C) Copyright jointly held by Springer and ESICM 2012

This editorial refers to the article available at: doi:10.1007/s00134-012-2648-3.

\author{
R. Endacott ( $\bullet)$ \\ University of Plymouth, Faculty of Health, Drake Circus, \\ Plymouth, Devon PL4 8AA, UK \\ e-mail: ruth.endacott@plymouth.ac.uk \\ Tel.: +44-17-52587488 \\ Fax: +44-17-52586482 \\ R. Endacott \\ Monash University, Faculty of Medicine, Nursing \& Health \\ Sciences, Clayton, Melbourne, VIC, Australia
}

The twin challenges of an increasingly co-morbid but more easily rousable patient population arguably increase workload for all professionals providing critical care. Over the past two decades there has been a greater focus on measuring workload for ICU nurses than for physicians [1]. At the same time evidence has been building of the impact of excess workload on patient safety, although it is also clear that high workload does not 'ipso facto' result in decreased safety [2]. Hence there is clearly some interaction of factors that changes an ICU with a high workload from a safe to an unsafe environment for patients.

Added to this complexity is the lack of agreement on what constitutes workload, ranging from the deceptively simple 'capacity to respond' [3] or 'cost of accomplishing a task' [4] to the detailed definition of 'a multidimensional and complex construct, that is affected by external task demands, environmental, organizational and psychological factors, and perceptive and cognitive abilities' [5]. The notion of cost is reflected in the three imperatives for studying workload: patient safety costs, staff wellbeing costs and service provision costs.

The impact of ICU workload on safety indicators is evidenced in studies investigating infection rates $[6,7]$ and medical errors [8] whilst attempts to find associations between nursing workload and patient mortality have yielded contradictory results $[9,10]$. However, it is clear that patient volume can also have a positive effect on patient outcomes [11].

There is enduring evidence of links between workload and stress $[10,12,13]$, both in terms of volume of work and the type of patients managed. The Conflicus study investigators found greater conflict between staff when nurses and physicians had been caring for dying patients or providing pre/post mortem care within the last week [14]. Physiological measures known to be sensitive to stress (such as heart rate, pupil diameter and respiratory rate) are used in some studies as indirect measures of workload [15], indicating an expectation that higher workload equates with higher stress.

Workload can be measured from the perspective of the tasks/patients or the 'worker' $[1,15]$. The patient-based approach uses two methods: the dependency method, for example nurse to patient ratio and patient acuity, which is often undermined by use of a 'fixed' approach such as 1:1 or 1:2 to staff all beds in a unit, or the activity method, which examines time spent on patient activity as a percentage of total time, using measures such as TISS-28 [16] or the nursing activities score (NAS) [17]. Both of these patient/task-based approaches are used for organising tasks, deciding on the staffing establishment and coping with patient severity and patient turnover. This approach is driven by increasing effectiveness and efficiency, with the goal of decreasing unnecessary nursing costs. Debergh and colleagues [18] report on the use of 
NAS to delineate between the workload of different shifts; in an increasingly cost-conscious environment, this is an important further piece of the workload puzzle, with shift work potentially impacting on patient safety and staff well-being, as well as the more obvious financial costs. However, the ability to take account of unit-based factors influencing workload remains unsolved and is necessary before these data can be used for comparison across units, a key consideration in an increasingly 'benchmark-orientated' health-care environment.

The worker-based approach takes the experience of the ICU nurse into account and is generally used for conceptual work, rather than for day-by-day staffing decisions; the purpose of this approach is to determine the amount of nursing effort resulting from each activity, examine causes of high workload and compare interventions for managing workload. Attempts to apply this type of measure on a routine basis have led authors to describe workload as 'uncountable' [19].

In an attempt to move this type of measurement forward, a 'worker-based' workload measure developed 20 years ago for aviation (the NASA task-load indexNASA-TLX) was applied to ICU nursing workload [15]. The NASA-TLX contains workload dimensions grouped into six domains: mental demand, physical demand, temporal demand, frustration, effort and performance; hence, it was felt by the research team (a combination of
ICU and aviation experts) to encapsulate the complexity of ICU nursing workload. As part of the analysis, they compared this operator-based tool with two patient-based tools (nurse to patient ratio and NAS) and demonstrated at best a moderate correlation (NASA-TLX with NAS: $r=0.45, p<0.01$ ) or no correlation (NASA-TLX with nurse to patient ratio: $r=0.10, p>0.05)$. This indicates that they are measuring different constructs and emphasises the need to continue with these parallel approaches to workload measurement.

The paper by Debergh and colleagues [18] sheds light on a previously ignored but important aspect of workload-comparison across shifts; the usefulness of this approach will only be evident when units replace a global nurse to patient ratio with some form of workload tool to plan staffing.

It is likely that ICU in the future will entail "application of more complex and costly procedures to an increasingly fragile population, where complications will have greater consequences due to increasingly narrow cost-effectiveness margin of interventions" [20]; hence, the spotlight will continue to fall on the most expensive ICU resource-nurse staffing. We need to continue to explore workload from the patient-based and workerbased perspective to improve both the way in which we staff ICUs and our understanding of sources of workload and ways in which excess workload can be ameliorated.

\section{References}

1. Rothe HU (2010) Organising the workflow in an ICU. In: Flaaten $\mathrm{H}$ et al (eds) Organisation and management of intensive care. MWV, Berlin, pp 225-239

2. Mountain SA, Hameed SM, Ayas NT, Norena M, Chittock DR, Wong H, Dodek P (2009) Effect of an ambient workload in the intensive care unit on mortality and time to discharge alive. Healthcare Quaterly 12 Spec No Patient, pp 8-14

3. Lysaght RJ, Hill SG, Dick AO, Plamondon BD, Linton PM, Wierwille WW, et al. (1989) Operator workload: comprehensive review and evaluation of operator workload methodologies (No. ARI Tech. Report 851). US Army Research Institute, Fort Bliss, TX

4. Hart SG (2006) NASA-task load index (NASA-TLX); 20 years later. Proceedings of the human factors and ergonomics society 50th annual meeting. Human Factors and Ergonomics Society, California, pp 904-908
5. Weinger MB, Reddy SB, Slagle JM (2004) Multiple measures of anaesthesia workload during teaching and nonteaching cases. Anaesth Analg 98:1419-1425

6. Cimiotti JP (2007) Staffing level: a determinant of late-onset ventilatorassociated pneumonia. Crit Care 11:154

7. Hugonnet S, Chevrolet JC, Pittet D (2007) The effect of workload on infection risk in critically ill patients. Crit Care Med 35:76-81

8. Landrigan CP, Rothschild JM, Cronin JW, Kaushal R, Burdick E, Katz JT, Lilly CM, Stone PH, Lockley SW, Bates DW, Czeisler CA (2004) Effect of reducing intern's work hours on serious medical errors in intensive care units. N Engl J Med 351:1838-1848

9. Tarnow-Mordi WO, Hau C, Warden A, Shearer AJ (2000) Hospital mortality in relation to staff workload: a 4 year study in an adult intensive care unit. Lancet 356:185-189
10. Kiekkas P, Sakellaropoulos GC, Brokalaki H, Manolis E, Samios A, Skartsani C, Baltopoulos GI (2008) Association between nursing workload and mortality of intensive care unit patients. J Nurs Scholarsh 40:385-390

11. Kahn JM, Goss CH, Heagerty PJ, Kramer AA, O'Brien CR, Rubenfeld GD (2006) Hospital volume and the outcomes of mechanical ventilation. N Engl J Med 355:41-50

12. Schaufeli W, Le Blanc P (1998) Personnel. In: Miranda DR, Ryan DW, Schaufeli WB, Fidler V (eds) Organisation and management of intensive care: a prospective study in 12 European countries. Springer, Berlin

13. Gurses AP, Carayon P, Wall M (2009) Impact of performance obstacles on intensive care nurse's workload, perceived quality and safety of care and quality of working life. Health Serv Res 44:422-443 
14. Azoulay E, Timsit JF, Sprung CL, Soares M, Rusinová K, Lafabrie A, Abizanda R, Svantesson M, Rubulotta F, Ricou B, Benoit D, Heyland D, Joynt G, Français A, Azeivedo-Maia P, Owczuk R, Benbenishty J, de Vita M, Valentin A, Ksomos A, Cohen S, Kompan L, Ho K, Abroug F, Kaarlola A, Gerlach H, Kyprianou T, Michalsen A, Chevret S, Schlemmer B; Conflicus Study Investigators and for the Ethics Section of the European Society of Intensive Care Medicine (2009)

Prevalence and factors of intensive care unit conflicts: the conflicus study. Am J Resp Crit Care Med 180:853-860
15. Hoonakker P, Carayon P, Gurses AP, Brown R, Khunlertkit A, McGuire K, Walker JM (2011) Measuring workload of ICU nurses with a questionnaire survey: the NASA task load index (TLX). IIE Trans Healthc Syst Eng $1: 131-143$

16. Miranda DR, de Rijk A, Schaufeli W (1996) Simplified therapeutic intervention scoring system: the TISS28 items-results from a multicenter study. Crit Care Med 24:64-73

17. Miranda DR, Nap R, De Rijk A, Schaufeli W, Iapichino G (2003) Nursing activities score. Crit Care Med $31: 374-382$
18. Debergh D, Myny D, Van Herzeele I, Van Maele G, Miranda D, Colardyn F (2012) Measuring the nursing workload per shift in the ICU. Intensive Care Med. doi:10.1007/s00134-012-2648-3

19. Taylor CJ, Bull F, Burdis C, Ferguson DG (1997) Workload management in A and $\mathrm{E}$ : counting the uncountable and predicting the unpredictable. J Accid Emerg Med 14:88-91

20. Moreno R, Rhodes A (2010) The intensive care unit of the future. In: Flaaten $\mathrm{H}$ et al (eds) Organisation and management of intensive care. MWV, Berlin, pp 399-403 